\title{
Transitivity and Mystification in a Contemporary Discourse Analysis of Trump's Inaugural Address
}

\author{
Rajaa Hamid Salih \\ Anbar Educational Directorate, Iraq
}

\begin{abstract}
In contemporary discourse analysis (CDA), transitivity refers to what Hart (2014) understood as "the type of process designated in the clause and the consequences of this for the types of participants that can occur in the clause" (p. 22). The purpose of this research is to analyze the transitivity and mystification in Trump's inaugural address.
\end{abstract}

Index Terms - discourse analysis, grammar and ideology, transitivity, mystification

\section{INTRODUCTION}

When President Trump made his inaugural speech on the National Mall in Washington, District of Columbia (DC) on January 20, 2017, audience members were awestruck by his declaration that he would make "America First!" However, the newly-elected President may have concealed intentions about how his core audience members-who largely consisted of White Christian conservatives from a rural background-should take political action and fulfill the goals of a broader ideological agenda. In the analysis that follows, the research on the linguistic processes of transitivity and mystification provides a basis for explaining how Trump succeeded in persuading his audience into believing that the United States could once again achieve victory in the global political landscape. Despite the criticisms that Trump incited violence in his audience members to fulfill a White nationalist agenda, the analysis here indicates that the moral and ethical implications of sweeping emotional appeals embedded in the declarative sentences of the inaugural address must receive closer attention by linguists.

\section{Discourse ANALYSIS OF Trump’s INAUgURAL ADDRESS IN JANUARY 2017}

The research that highlights transitivity indicates that the distribution of material, relational, mental, verbal, behavioral, and existential processes matter significantly when major political leaders deliver an inaugural address that contains a central argument recommending solutions to persistent social or economic problems. For example, the inaugural speech delivered by President Donald Trump in January 2017 had a high percentage of material processes as indicated in clauses containing an actor and involving a goal (Hart, 2014; Liao \& Han, 2019). Relational processes represented the second-highest occurring incidences of transitivity in Trump's inaugural speech such that audience members drew abstractions and constructed ideas of what his central argument about making "America First!" could have meant (Bello, 2016, p. 3). Here, the relational processes used by Trump during his inaugural address imply that each problem addressed has a close and proximate relationship to one another (Valdés-Miyares, 2018). This type of relationship indicates that linguists who perform a discourse analysis must also consider how the social or economic problems identified in political speeches may risk appropriation by an orator who uses fallacious rhetorical strategies to gain attention and shape public opinion.

Mental processes represented the third-highest occurring incidents of transitivity in Trump's inaugural address to suggest that the newly-elected President appealed heavily to the emotions when making his central argument. More specifically, President Trump appealed to the emotions of audience members who believed that the military service members who died during the wars in Iraq and Afghanistan were "forgotten" and that they "will be forgotten no longer" (Liao \& Han, 2019, pp. 803-4). Here, Trump doubles down further by using the first-person plural to suggest that a nation can survive only if its citizens have the wherewithal to support his Presidential administration and ensure that the public will never forget the death of a military service member.

Although Trump did not use mental processes with a high degree of frequency compared to material processes, the newly-elected President understood that the nominalization of multiple problems would appeal to audience members who already felt uncritically negative toward immigration and who maintained positive views of militarism in the United States. In acknowledging one minor of social progress, however, Trump acknowledged that women were actors who represented the "forgotten" military service members who died in Iraq and Afghanistan (Liao \& Han, 2019, p. 804). While Trump appeals to a broadly conservative audience, the mental processes used during his inaugural address reflected a need for all American citizens to define all military service members performing heroic duties while on a combat tour. 
Existential and behavioral processes had a much lower frequency in Trump's inaugural address as indicated by how the newly-elected President of the United States established grounded the meaning of existence among audience members who interacted with the physical environment in a particular way. Liao and Han (2019) noted how existential processes often provide objective descriptions to situations demanding urgent attention. Existential processes make the content of speeches convincing enough for audience members to engage in political activity while maintaining their core identity as working-class conservative adults. Yet, this line of the research on CDA indicates that overusing existential processes dulls the emotional impact of speeches (Liao \& Han, 2019). Regardless of the emotional appeals made by Trump during his inaugural address, the existential processes were barely present and did not encourage audience members to question the underlying meaning of their belief systems.

Even the slightest overuse of existential processes in Trump's inaugural address would have challenged the core constituency of audience members to such an extent that the degree of loyalty toward the political leader would have dramatically changed. Still, Hart (2014) reminds linguists who perform CDA that existential processes are minor insofar as their lexicogrammatical placement in speeches follows an elliptical queue. The newly-elected President did not want his audience members to question his emotional appeals. Instead, Trump wanted his audience to refrain from taking a passive stance on issues considered meaningful in their existence.

Concerning the behavioral processes, their lower frequency rates in Trump's inaugural address indicated that the newly-elected President did not want audience members to think deeply about the relationship between physiological and psychological activities. Behavioral processes straddle the border between material and mental processes such that conscious states emerge from the words used by President Trump in his speech (Liao \& Han, 2019; Sharififar \& Rahimi, 2015). While used infrequently, the behavioral processes in Trump's inaugural address indicated that audience members would take political action by acting unconsciously in targeting more than one racial minority group as the cause of issues like unemployment (Liao \& Han, 2019; Valdés-Miyares, 2018). By designating “America First!” as his central argument, Trump sparingly relied on behavioral processes to suggest that only citizens who identify as fully American should maintain full political rights.

For Trump, "real" Americans are the actors who deserve recognition as representing a social class with members who work hard to maintain their hard-earned and constitutionally protected freedom (Hart, 2014; Liao \& Han, 2019 , pp. 802-3). Yet, Trump suggested further in his inaugural address that real Americans must behave in a manner that conforms to conservative ideology. The behavioral processes included in Trump's inaugural address indicate, furthermore, that real Americans are of White ethnicity and come from a predominantly rural background (ValdésMiyares, 2018). Regardless of how most Americans live in urban environments, the central argument made by Trump is that his audience members represent a forgotten segment of the general national population.

Ironically, yet perhaps not surprisingly, verbal processes represented the least frequent occurrence of transitivity in Trump's inaugural address. Verbal processes refer to the construction of symbolic relationships that convey meaning while framed in human consciousness (Liao \& Han, 2019). Verbal processes also involve a "sayer" but do not always need to involve a receiver (Hart, 2014, p. 23). While verbal processes occasionally have an ideological effect on audiences, their requirements established in relation to material processes apply almost exclusively at the semantic level. Similarly, the clauses in a speech are not explicit when verbal processes are rare (Hart, 2014; Liao \& Han, 2019). Despite their rarity in Trump's inaugural address, verbal processes may indicate a high level of formality and directness that reflects the need to make a speech sound rhetorically impressive (Liao \& Han, 2019). For example, Trump quoted verses from the Holy Bible in appealing to a White, Christian, rural, and politically conservative audience who believed that the United States has been traveling down the wrong path for years.

For the recipients of Trump's inaugural address, the Bible verses provided comfort and reassurance to those who believed that most American citizens have strayed away from what God originally intended for them. In using Bible verses as a rhetorical device, however, Trump used the verbal processes of his inaugural address to practice mystification. From a point of view lens, the use of transitivity gave way to mystification such that the distribution of six linguistic processes required an abdication of personal responsibility for causing an increase in the number of crimes targeting racial minorities and immigrants in the United States (Hart, 2014, 2015). While Trump presented the impression of showing empathy for everyone, he effectively used transitivity and mystification to arouse the emotions of his core audience members who believed that racial minorities and immigrants caused them significant economic harm. Here, mystification was present insofar as Trump declared the United States a national territory with significant rhetorical staying power that forged a mythical collective imagination that also encapsulated a personal identity (Valdés-Miyares, 2018). Mystification was also present in Trump's inaugural address when his underlying intent was to have his core audience use political violence as a tool of ethnic-based exclusion.

Loadenthal (2019) noted how the use of mystification represents a deliberate attempt to romanticize stereotypes of a racialized "Other" who does not fit the stereotypical image of what a Christian nation-state should resemble (p. 80). Accordingly, the ideological components included in speeches like Trump's inaugural address reflect an attempt to divide and conquer a minority group by asserting that all citizens should work together as equals. For Trump, noncitizens who entered the United States illegally and most non-Whites do not fit the "forgotten" rural White Christian archetype of a "real" American (Liao \& Han, 2019; Loadenthal, 2019). Yet, the audience members who received Trump's speech were not considered extremists judged by the rhetorical value of Christian conservativism. Although 
many Trump supports harbor White supremacist and anti-immigrant views, the rhetorical statements included in the inaugural address were shrouded in a patriotic cloak that obscured the original intent of promoting violence for political purposes. While many linguists would agree that Trump aimed to incite terroristic violence by citing Bible verses and couching his arguments in White supremacy, the mystification present in the inaugural speech reflected speech patterns in which active constructions were ideological points of departure for taking political action.

Recalling Hart (2014), mystification refers to the ideological impacts of obscuring the intentional intent underlying a speech or written text. While Trump used his position as a newly-elected President, the inaugural address represented an exercise in state power suggesting that a White Christian conservative constituency must take responsibility for establishing ideological goals. However, the ideological functions of mystification indicated that nominalization was necessary to establish lexicogrammatical patterns when Trump named one problem as containing multiple and layered meanings. Nominalization entails that Trump wanted his audience members to conceal the underlying intent of their actions. Here, Trump's inaugural address contained an implied message that all "real" Americans should reduce ideological situations to their simplest components (Hart, 2014, p. 33). An us-versus-them logic rooted in a divide-andconquer mentality was remarkably clear in Trump's inaugural address. However, nominalization was also present when Trump effectively utilized mystification as a linguistic tool for defining his audience members as agentless passives.

By defining a White Christian conservative as agentless passives, Trump reduced all political processes to their simplest by components by suggesting that all major issues had no room for debate or other mitigating circumstances. For Trump, recovering the agency of his core audience members required mystification through nominalization when the newly elected President filled an "empty slot" in clause structures and created a "congruent" representation of what the American political landscape of the United States should resemble (Hart, 2014, p. 33). Ironically, Trump used mystification through nominalization by unpacking multiple rhetorical strategies and defining agentless passives as fully capable of fulfilling broader ideological goals.

Trump also relied on mystification through nominalization in suggesting that all members of his core constituency must receive closer attention by a mass media that either ignored them or deliberately undermined their capacity for agency. For example, the "forgotten" service members who fought in the military reflected a congruent representation of what Trump believed should complete an ideological landscape (Hart, 2014; Liao \& Han, 2019, pp. 803-4). Trump suggested further in his inaugural address that military service members restore nationalist sentiments by providing a White rural conservative Christian constituency with the agency required to achieve overarching political objectives. By relying on nominalization, Trump effectively used mystification as a linguistic framework for transforming agentless passives into active agents (Hart, 2014). Although the audience members who received Trump's inaugural address may not appear to have violent tendencies, the presence of nominalization indicated that the newly elected President concealed his intent to have violence carried out in the fulfillment of religious, political, and, ideological goals.

Yet, the presence of nominalization indicated that the linguistic structures present in Trump's inaugural address were significant when the newly-elected President abused discursive power. By defining the capacity for his audience members to play social actors, Trump found ideological potential in multiple contexts that made sense when cobbled together as a sweeping emotional appeal to political action (Hart, 2014). However, Trump defined his audience members as agentless passives who needed to restore balance in the current political order. If violence was necessary to restore such an order, the mystification that guided the linguistic structures used by Trump indicated further that all ideological constructions of political discourse merely represent small-scale examples of where power may lie.

Yet, the use of mystification in Trump's inaugural address included linguistic structures suggesting that his core audience members represented a statistically significant minority who felt ideologically powerless (Hart, 2014; ValdésMiyares, 2018). Partly because Trump lacked the support for his assumptions, however, he resorted to making emotional appeals and using overgeneralized statements about political enemies who threatened an established order. Considering the linguistic structures used in Trump's inaugural address, the lack of accurate statistical data reinforced the problems that result from not accounting for what most Americans believe will improve political and ideological systems.

Specific to nominalization, the linguistic constructions of Trump's inaugural address reflected a deliberate attempt to move away from their appearance in written genres and establish a type of scientific register. Bello (2016) noted how, over the past four to five centuries, the linguistic structures of written texts developed into more complex forms of nominalization. Nominal groups have now replaced verbs as the cause for establishing ideological processes and recommending that audiences take political action by relying on slogans like "America First!" The intent here is clear insomuch as Trump engaged in mystification to forge an emotional bond between himself and his core audience members.

Yet, nominalization contributes to CDA scholarship by encapsulating rhetorical devices as equally cohesive and coherent. By defining White Christian rural conservatives and fallen military service members as agentless passives, Trump established a concise linguistic backdrop for making rhetorical claims about the population that believed was statistically forgotten (Bello, 2016; Liao \& Han, 2019). Trump also relied on mystification through nominalization as fundamental to constructing a linguistic framework that effectively codified a new form of "learning" for his core constituency (Bello, 2016, p. 4). For Trump, new ways of thinking and speaking were necessary to establish an 
ideological community of practice that claimed to defend the truth yet denied the merits of accurate scientific knowledge.

While nominalization initially received scant attention by linguists, more recent sources included suggestions that its purpose is to help orators avoid repetition. Nominalization bears some degree of similarity to the verbal processes of transitivity when orators strive to achieve lexicogrammatical cohesion and ensure the coherence of ideas (Bello, 2016; Hart, 2014, 2015; Liao \& Han, 2019). Yet, this linguistic feature of mystification typically serves to improve textual structures. In terms of formal speeches, nominalization attributes factuality to verbal processes when orators use reification when presenting ideas as if they were bound to empirical reality (Bello, 2016). Linked to Trump's inaugural address, the reifying elements of nominalization were present when the newly-elected President attempted to introduce a new scientific discourse in which all problems impacting a White rural Christian conservative constituency requires strong political action.

Trump used nominalization in this manner to ensure his audience members that they, too, possess the linguistic and scientific knowledge considered useful for participating in rigorous ideological discourse. Yet, Trump used this feature of mystification to ensure that his audience members would not dispute his authority as President of the United States (Bello, 2016; Liao \& Han, 2019). If Trump included any ambiguous statements in his inaugural address, the intent of his message would have remained unclear and his audience members would have asked questions about its original intent. Accordingly, the use of nominalization through mystification by Trump was remarkably effective in using cohesive linguistic structures to disseminate a clear message easily understood by audience members who lacked academic training in scientific methods. The use of nominalization also helped Trump ensure that his new role as President reproduced a White supremacist ideology and maintained imbalanced power relationships (Bello, 2016). Moreover, the use of nominalization allowed Trump to underpin the linguistic structures of his inaugural address by relying on shifts in angle and whole-for-part metonymies.

Hart $(2015$, p. 252$)$ explained in his research that shifts in angle impact the "trajectory of [a] sightline" and the "granularity of [an] image" when speech events occur. Accordingly, Trump invoked a point of view from one specific angle in his inaugural address by positioning his central argument above an event space- the National Mall — and by viewing the potentiality of his results as an overview. By using nominalization, however, Trump ensured his ability to reduce clauses to their simplest components by reifying a series of common relationships between ideas and the inaugural event itself. For Trump, nominalization helped the newly-elected President paint a Gestalt by involving participants and circumstances when construing linguistic processes as having profound existential consequences (Hart, 2015). Ironically, the infrequent linguistic referents to existential processes reinforced an ideological perspective that his audience members could not question (Liao \& Han, 2019). Since orators rarely use existential processes in speeches, Trump effectively ensured that his audience members would accept his rhetorically-grounded linguistic turns of phrase at face value.

Likewise, the use of nominalization in Trump's inaugural speech signified a whole-for-part metonymy that evoked the notion of granularity in relation to lexicogrammatical properties. Hart (2015) explained further here how orators may use whole-for-part metonymies by conceiving linguistic structures as belonging to a homogenized mass. In effect, Trump cherry-picked from multiple issues by encouraging the audience members who witnessed his inaugural address to believe that one instance belonging to one category represents an entire problem that requires an immediate solution. Whether that solution involved audience members resorting to political violence reinforced how Trump used mystification to his advantage (Hart, 2014, 2015; Liao \& Han, 2019). Nevertheless, the whole-for-part metonymy used by Trump in his inaugural address served a purpose of generalizing opinions about which political strategies would serve ideological goals. The point of view expressed by Trump indicated further that strong forms of political action were necessary to achieve maximum impact.

Trump used the whole-for-part metonymy by assuming that all members of his core audience held similar beliefs about major social, political, and economic issues impacting their livelihood. However, he also used the agentless passive voice to focus almost exclusively on the results of interactions between speaker and audience (Hart, 2015; Ping \& Lingling, 2017). To the extent that he attributed causes to the social, political, and economic issues negatively impacting the livelihood of his audience members, Trump relied on the whole-for-part metonymy by intentionally distancing himself from having any causal relationship to future problems that entailed the infliction of violence for political or ideological reasons.

Going even further, the linguistic structures used in Trump's inaugural address reflected a co-optation of antiglobalization discourse. The CDA research by $\mathrm{Ar}$ (2015) indicated that the relationship between language and society is so complex yet receives scant attention. Instead, this relationship has its linguistic roots in concrete texts and social practices. Traditional and abstract explorations of ideology also ground this relationship. Placed within the context of Trump's inaugural address, the anti-globalization rhetoric helped audience members forge a pseudo-scientific connection between macro-level issues and micro-level structures. Yet, Trump engaged in mystification by deliberately misrepresenting globalization and obfuscating its definition constructed by economists and social scientists.

By invoking the anti-globalization discourse, Trump also engaged in mystification through parallelism when the newly-elected President relied on syntactical and lexical similarities across sentences as well as inside clauses and phrases (Hart, 2014; Kazemian \& Hashemi, 2014). Parallelism was also present when Trump reiterated the clauses of 
material processes in distinguishing his inner experience of globalization from that of his core audience members (Kazemian \& Hashemi, 2014; Liao \& Ham, 2019). Accordingly, Trump defined the actors of parallel statements against globalization as likely to transform as new political and economic processes unfold in the United States. The actors used in parallel statements also ensured that Trump would contribute balance and rhythm while clarifying the linguistic structures of his rhetorical claims.

Trump attempted to unify linguistic structures and rhetorical strategies by providing his audience members with the impression that globalization had links to immigration that caused unemployment rates to increase in rural or impoverished communities of the United States (Kazemian \& Hashemi, 2014; Liao \& Ham, 2019; Valdés-Miyares, 2018). However, Trump engaged in mystification by implicitly recommending that his audience members refrain from making stark comparisons and contrasts of ideas expressed in the inaugural address. While the subject, predicates, adverbs, and direct objects of clauses articulated by Trump were clear, their intent was to exploit the emotional vulnerabilities of audience members who lacked critical thinking skills.

Recalling the distinction between theme and rheme, Trump engaged in mystification through nominalization by introducing information about the relationship between global and local issues to his audience members (Hart, 2014, Liao \& Han, 2019). Here, the linguistic structures of Trump's inaugural address also contained anaphoric referents that linked back to meaningful ideas already used during the speech (Bello, 2016; Liao \& Han, 2019). Whereas the overarching theme of Trump's inaugural address represented a central argument of making America "first," the rheme signified an unmarked construction in the mind of his core audience members who uncritically received information that already conformed to a conservative ideological perspective (Bello, 2016; Hart, 2014; Liao \& Han, 2019). Through nominalization, Trump implied that each rheme would signify a unique embedded in the cognitive framework of his core audience members.

Whereas the overarching theme and central argument of "America First!" suggests that the nation-state represents the actor, Trump deliberately engaged in mystification by relying on material linguistic processes to conflate the actor and its goal (Hart, 2014; Liao \& Han, 2019). Thus, Trump engaged in mystification by issuing marked declaratives and also defining agentless passives as capable of leading to charge to reinstate the United States as a leader in global economic trade. In so doing, Trump nevertheless conflated theme and rheme by issuing declarative statements that eventually led the charge to reinstate White nationalism through a discourse of Othering perceived and real enemies.

In many ways, the type of mystification executed by Donald Trump in his inaugural address symbolized a quixotic view of the United States defeating terrorism in the Middle East by increasing military power. By exploiting the emotional vulnerabilities of a White rural Christian conservative audience, Trump reinstated an Orientalist discourse to suit his needs and identify an enemy that threatened the political stability of a Western nation-state (Loadenthal, 2019). Yet, the nationalist rhetoric advanced by Trump suggests that Americans who maintain strong religious views and work hard but lack critical thinking skills should already know the solution to problems associated with globalization. For Trump, the solution to problems caused by globalization involves engaging in politeness strategies that will eventually undercut their efforts (Ar, 2015; Loadenthal, 2019). However, the use of mystification in Trump's inaugural address remains apparent insofar as the ideological claims include grammatical references belonging outside a nationalist context.

In sum, the applications of transitivity and mystification in Trump's inaugural speech indicated that the newlyelected President relied on making emotional appeals in exploiting the fact that most of his audience members have Christian religious views, come from a rural background, and feel compelled to blame a global enemy for their lack of prosperity. The linguistic features of Trump's inaugural address indicated further how theme and rheme galvanized a nationalist discourse from which patriotic audience members relied on an ideological stance to take political action. Despite how the linguistic and rhetorical aspects of Trump's inaugural speech indicated that violence was sometimes necessary to achieve the overarching political goals, they reflect how strongly the President relied on defining his core audience members as agentless passives who searched for inspiration and suddenly found it in a charismatic executive leader.

\section{DISCUSSION}

The application of transitivity and mystification in Trump's inaugural address opens the door to answering numerous questions about what may lie ahead regarding the relationship between linguistics and ideology. CDA scholars delineate this relationship as a forged union between language studies and social theory such that analyses of power and its possible misuse require ongoing attention (Sharififar \& Rahimi, 2015). In turn, the relationship between language, ideology, and power informs CDA scholarship by presenting a system to analyze the rhetorical value of clauses used by leaders of nation-states who make sweeping emotional appeals to take political action. When leaders of nation-states make emotion-laden appeals to action, the intent to pass along vital information is clear. Linguistically and rhetorically, the descriptive and expressive functions also have grammatical implications for identifying where transitivity and mystification have their presence in formal speeches.

Ping and Lingling $(2017$, p. 29) drew from the SFG scholarship to delineate three "meta-functions" of grammatical phenomena that provide a basis for explaining the relationship between language, ideology, and power in formal speeches. First, the ideational function provides the basis for explaining how orators construct human experience by 
making sense of "reality" and contextualizing it within transitivity (Ping \& Lingling, 2017, p. 29). Transitivity provides the linguistic basis for explaining and contextualizing reality in formal speeches by inviting CDA scholars to evaluate whole clauses for their process, the number of participants or audience members affected, and the roles played by each participant or audience member.

While the audience members who witnessed Trump's inaugural speech may latch onto one or more keywords in a single clause, the emotional impact of the entire clause may contain more meaning than originally intended. Here, mystification occurs when the ideational function does not suffice to explain how orators construct human experience (Hart, 2014; Ping \& Lingling, 2017). While Trump highlighted the "forgotten" experiences of fallen military service members and a rural White Christian constituency, he may likely have concealed his original intent to incite his audience into taking political action by almost any means necessary (Liao \& Han, 2019, p. 804). By emphasizing presumably forgotten experiences, Trump called on the support of his audience members to act out their ideological persuasions but neglected to introduce any recommendations conducive to achieving the policy aims of his nationalist agenda.

Secondly, the interpersonal function provides a basis for using language when orators communicate their views to forge lasting relationships with an audience. Ping and Lingling (2017) noted further how the interpersonal function also can involve an orator encouraging audience members to improve the social and economic circumstances. The rhetorical device of tone is especially important to recognize when orators make sweeping emotional appeals and issue declarative statements about how society must function (Valdés-Miyares, 2018). In his inaugural address, Trump issued declarative statements with a tone that did not necessarily invoke an immediate emotional response from his audience members. Instead, the declarative statements issued by Trump may have indicated an intent to establish constructive dialogue between individuals who hold opposing ideological views on serious political issues like militarization, globalization, immigration, White supremacy, religious freedom, and economic prosperity (Ar, 2015; Bello, 2016; Liao \& Han, 2019; Loadenthal, 2019; Ping \& Lingling, 2017). Declarative statements also entail orators making sweeping emotional appeals to make the substance of their clauses sound more convincing.

In the CDA research, declarative statements made orators play the role of informing audience members about speech functions that convey an intent to arouse ideologically-oriented emotions. When issuing his declarative statement to make "America First!" Trump cast himself as a motivational speaker who thoroughly understood the difference between active and passive phrases. Throughout his inaugural address, Trump used the passive voice sparingly in declaring his intent while he also targeted the agentless passive who demand an inspirational voice in political speechmaking (Hart, 2014; Ping \& Lingling, 2017). The active voice was prominent throughout Trump's inaugural address in suggesting that the newly elected President would take every step necessary to provide his constituency with an enhanced sense of agency. By using the active voice, Trump was able to strengthen the interpersonal relationships with his audience members and convince them into believing that broader political action was necessary to restore the public faith in American politics. Moreover, Trump supplied the phenomena explaining the relationship between language, ideology, and power in public speaking.

Thirdly, the textual function provides a basis for understanding how orators construct rhetorical arguments by situating them within an ever-evolving system of language use. The textual function also relates to the lexicogrammatical cohesion of a formal speech by "creating focus and emphasis" and by establishing a general mood for audiences to embrace (Ping \& Lingling, 2017, p. 30). Linguistically, however, the textual function has a relationship to transitivity and mystification to the extent that Trump effectively used nominalization in his inaugural address. For Trump, nominalization provided a link between the subject and the finite by orating imperative clauses along with declarative statements (Bello, 2016; Hart, 2014, 2015; Liao \& Han, 2019). Imperative clauses have the potential to incite political action when a newly-elected leader calls upon an audience to engage in moral decision-making. Since a considerable portion of Trump's audience comes from a White rural Christian conservative background, imperative clauses deserve more attention in future studies that involve linguists performing a discourse analysis.

Within the context of transitivity and mystification, future research studies on imperative clauses may encourage linguists to analyze the textual forms and structures of Trump's inaugural address by working toward closing gaps between language and society (Hart, 2014; Kazemian \& Hashemi, 2014). More importantly, future research studies on imperative clauses may help CDA scholars close gaps between linguistic constructions and subjectivity in audience members (Kazemian \& Hashemi, 2014). While attention to the former has significant lexicogrammatical implications for assessing the ethical integrity of sweeping emotional appeals made by Trump in his inaugural address, the latter suggests that commitments to taking political action must always have an ethical basis even if audience members commit violence for ideological, religious, or political reasons (Valdés-Miyares, 2018). As such, the future scholarly attention given to Trump's inaugural address must reinforce how transitivity and mystification anchor the relationship between language, ideology, and power.

\section{CONCLUSION}

The preceding analysis drew from CDA scholarship on transitivity and mystification to account for how President Donald Trump relied on these linguistic processes while issuing declarative statements about how the United States should improve. By appealing to an audience that represented the lowest common denominator, Trump understood that 
his observers and listeners constituted agentless passives desperate for inspiration. Yet, the applications of transitivity and mystification in Trump's inaugural address indicated that the newly-elected President made sweeping emotional appeals to make each clause in his speech sound convincing on lexicogrammatical and rhetorical levels. Regarding each of the six processes, the actor and goal contained in each declarative sentence were of further significance for identifying the moral implications of Trump encouraging his audience members to take political action. Yet, the overarching theme of "America First!" and the rheme of each issue identified in the inaugural address suggested further that the relationship between language, ideology, and politics must include causal connections between intent and outcome. While Trump may not have wanted his audience to support a White nationalist ideological agenda, he likely understood that the bulk of a White rural conservative Christian base holds anti-immigrant and anti-globalization sentiments yet lacks the critical thinking skills needed to develop an informed opinion on these subjects. As such, the imperative clauses deserve closer attention in future research studies whereby linguists may assess the ethical impacts of declarative statements made by Trump in his inaugural address.

\section{REFERENCES}

[1] Ar, M. (2015). Language and ideology in texts on globalization: A critical discourse analysis. International Journal of English Linguistics, 5(2), 63-78. doi: 10.5539/ijel.v5n2p63.

[2] Bello, I. (2016). Cognitive implications of nominalizations in the advancement of scientific discourse. International Journal of English Studies, 16(2), 1-23. doi: 10.6018/ijes/2016/2/262921.

[3] Hart, C. (2014). Discourse, grammar and ideology: Functional and cognitive perspectives. London, UK: Bloomsbury Academic.

[4] Hart, C. (2015). Viewpoint in linguistic discourse: Space and evaluation in news reports of political protests. Critical Discourse Studies, 12(3), 238-260. doi: 10.1080/17405904.2015.1013479.

[5] Kazemian, B., \& Hashemi, S. (2014). Critical discourse analysis of Barack Obama's 2012 speeches: Views from systemic functional linguistics and rhetoric. Theory and Practice in Language Studies, 4(6), 1178=1187. doi: 10.4304/tpls.4.6.1178-1187.

[6] Liao, G., \& Han, G. (2019). Ideological differences between America and China from perspectives of transitivity systemIllustrated by Trump's and Xi Jinping's presidential inaugural addresses. Journal of Language Teaching and Research, 10(4), 800-806. doi: 10.17507/jltr.1004.16.

[7] Loadenthal, L. (2019). Othering terrorism: A rhetorical strategy of strategic labeling. Genocide Studies and Prevention: An International Journal, 13(2), 74-105. doi: 10.5038/1911-9933.13.2.1704.

[8] Ping, K., \& Lingling, L. (2017). Application of interpersonal meaning in Hillary's and Trump's election speeches. Advances in Language in Literary Studies, 8(6), 28-36. doi: 10.7575/aiac.alls.v.8n.6p.28.

[9] Sharififar, M., \& Rahimi, E. (2015). Critical discourse analysis of political speeches: A case study of Obama's and Rouhani's speeches at UN. Theory and Practice in Language Studies, 5(2), 343-349. doi: 10.17507/tpls.0502.14.

[10] Valdés-Miyares, J. R. (2018). The strategies of ultranationalist discourse: This is England and Brexit. Open Cultural Studies, 2 , 50-60. doi: 10.1515/culture-2018-0006.

Rajaa Hamid Salih, works at the ministry of education at Anbar educational directorate in Iraq as an English teacher. I got master from the university of Bucharest, specialization in English Linguistics, Methods and Applications. Researcher in discourse analysis at the field of linguistic analysis. 